University of Nebraska - Lincoln

DigitalCommons@University of Nebraska - Lincoln

2006

\title{
Conspecific Attraction in a Grassland Bird, the Baird's Sparrow
}

\author{
Marissa A. Ahlering \\ University of Missouri - Columbia \\ Douglas H. Johnson \\ USGS Northern Prairie Wildlife Research Center, Douglas_H_Johnson@usgs.gov \\ John Faaborg \\ University of Missouri, Columbia, FaaborgJ@missouri.edu
}

Follow this and additional works at: https://digitalcommons.unl.edu/usgsnpwrc

Part of the Other International and Area Studies Commons

Ahlering, Marissa A.; Johnson, Douglas H.; and Faaborg, John, "Conspecific Attraction in a Grassland Bird, the Baird's Sparrow" (2006). USGS Northern Prairie Wildlife Research Center. 33.

https://digitalcommons.unl.edu/usgsnpwrc/33

This Article is brought to you for free and open access by the US Geological Survey at DigitalCommons@University of Nebraska - Lincoln. It has been accepted for inclusion in USGS Northern Prairie Wildlife Research Center by an authorized administrator of DigitalCommons@University of Nebraska - Lincoln. 


\title{
Conspecific attraction in a grassland bird, the Baird's Sparrow
}

\author{
Marissa A. Ahlering, ${ }^{1,3}$ Douglas H. Johnson, ${ }^{2}$ and John Faaborg ${ }^{1}$ \\ ${ }^{1}$ Division of Biological Sciences, University of Missouri, 225 Tucker Hall, Columbia, Missouri 65211, USA \\ ${ }^{2}$ USGS, Northern Prairie Wildlife Research Center, 204 Hodson Hall, 1980 Folwell Ave., St. Paul,
} Minnesota 55108 USA

Received 27 March 2006; accepted 21 August 2006

\begin{abstract}
Territorial songbirds generally use song to defend territories and attract mates, but conspecific song may also serve as a cue to attract other male songbirds to a breeding site. Although known to occur in some colonial and forest-associated species, only recently have investigators examined conspecific attraction in grassland species. We used a playback experiment to examine the possible role of conspecific attraction for males searching for potentially suitable breeding habitat in a grassland specialist, the Baird's Sparrow (Ammodramus bairdii). Experimental playback plots and control plots with similar landscape and vegetation characteristics were established at two sites in North Dakota. Baird's Sparrows colonized three of six experimental plots and none of six control plots. Males on experimental plots established territories adjacent to the playback stations and were sometimes observed counter-singing with the playback of conspecific songs. Vegetation characteristics were similar on all study plots, and did not explain differences in bird density on our treatment plots. Although we found that playback of conspecific songs attracted male Baird's Sparrows to previously unoccupied, potentially suitable habitat, further experiments are needed to examine the importance of conspecific attraction relative to other cues that birds may use, such as vegetation features. The conservation and management implications of conspecific attraction are not completely understood, but the presence of conspecifics should be considered as a potential cue in habitat selection by all species of birds.
\end{abstract}

\section{SINOPSIS. Atracción de congéneres en aves de hierbazales Ammodramus bairdii}

Las aves canoras territoriales generalmente usan su canto para defender sus territorios y atraer parejas prospectivas. Sin embargo, el canto de congéneres también se puede usar como una pista para atraer a otros machos a áreas reproductivas. Aunque se sabe que esto ocurre en algunas especies coloniales y algunas asociadas a bosques, fue recientemente que los investigadores examinaron este tipo de atracción en aves de hierbazales. Experimentamos con grabaciones para examinar el rol de la atracción de congéneres en un área potencialmente adecuada para la reproducción de Ammodramus bairdii, un especialista de hierbazales. Se establecieron lotes experimentales y controles, con características adecuadas para la especie, en dos localidades de Dakota del Norte. En los experimentales se hizo uso de grabaciones, para atraer a las aves. Los gorriones colonizaron tres de los seis lotes experimentales y ninguno de los controles. Hubo machos que establecieron territorios adyacentes a los lugares en donde se utilizaron las grabaciones. Se observó responder con su canto a las grabaciones a aquellos que llegaron. La vegetación fue similar en cada lote experimental y no se pudo utilizar para explicar diferencias en la densidad de las aves. Aunque encontramos que las grabaciones del canto de congéneres atraen a machos del Gorrión de Baird a lugares no ocupados con hábitat adecuado, se necesitan otros experimentos para examinar la importancia de atracción de congéneres, en relación a otras pistas, que las aves puedan utilizar para colonizar áreas apropiadas para estas. Las implicaciones de conservación y manejo de la atracción de congéneres no se entiende en su totalidad. Pero la presencia de congéneres debe ser considerada como una pista potencial en la selección de habitat por parte de las aves en general.

Key words: Ammodramus bairdii, Baird's Sparrow, conspecific attraction, habitat selection, playback experiment

Cues used to select breeding territories are poorly understood for many bird species. For territorial species, the classic model for habitat selection is that territory defense acts either as a signal about the number of occupants in the area or as a deterrent to settling in the area (Fretwell

\footnotetext{
${ }^{3}$ Corresponding author. Email: AhleringM@ missouri.edu
}

and Lucas 1970). However, for colonial-nesting species and some forest-associated territorial species, the presence of conspecifics can stimulate other birds to settle in an area (Danchin et al. 1998, Suryan and Irons 2001, Serrano et al. 2004, Ward and Schlossberg 2004, Hahn and Silverman 2006). Although conspecific attraction may seem counter-intuitive for territorial birds, there are potential advantages. One such advantage may be benefits gained through social 
aggregation. Aggregations of territorial males could benefit males by increasing their ability to attract mates, defend nests from predators, or obtain extra-pair copulations (Stamps 1988, Etterson 2003). Even in socially monogamous species, females and males may prefer territorial aggregations to increase opportunities for extra-pair copulations (Tarof and Ratcliffe 2004) and create hidden leks (Wagner 1998, Tarof et al. 2005, Fletcher and Miller 2006). Additionally, males may use the presence or reproductive success of conspecific males as a source of information about habitat suitability (Doligez et al. 2002, 2004, Sergio and Penteriani 2005).

Conspecific attraction has been demonstrated for colonial-nesting and some forest-associated passerine species, but has only recently been examined in grassland-associated species (Etterson 2003, Nocera et al. 2006). Grasslands are disturbance-dependent ecosystems characterized by spatial and temporal variability (Bragg 1995, Bragg and Steuter 1996). Disturbance and climatic variability create a mosaic of habitat quality. Although some species of grassland birds return to previous breeding sites (Bollinger 1989), several grassland birds, including Baird's Sparrows (Ammodramus bairdii), have adapted to this variability by exhibiting nomadic tendencies (Green 1992) and local population fluctuations (George et al. 1992, Zimmerman 1992, Igl and Johnson 1999). The presence of conspecifics could be an important cue for species that establish territories in new locations each year. Even though males would not have information about reproductive success at that location from the previous year and could not reliably use the presence of conspecific birds as an indication of previous nest success at that location (Bollinger and Gavin 1989, Doligez et al. 2002), birds may be able to use the presence of conspecifics as a cue concerning the location of potentially suitable breeding habitat in heterogeneous habitat.

For some species, clumped distributions that could have resulted from conspecific attraction have been observed (Skipper 1998, Tarof and Ratcliffe 2004). However, distinguishing the influence of habitat variability on such distributions from that of the presence of conspecifics is difficult. We used an experimental approach to determine whether Baird's Sparrows use conspecific attraction as a cue when selecting breeding territories. Baird's Sparrows are grassland specialists that breed in the north- ern Great Plains, including North Dakota and Montana, USA, and from southern Alberta to southwestern Manitoba, Canada, and winter in the southern United States and northern Mexico (Green et al. 2002). In North Dakota, Baird's Sparrow populations have been declining since at least the start of the Breeding Bird Survey in 1967 (Sauer et al. 2005), and determining whether these sparrows use the presence of conspecifics as cues for settlement could aid in the management and remediation of their declining populations. We chose to study Baird's Sparrows because they exhibit the clumped distributions characteristic of many grassland birds on both local and landscape levels, and it is relatively easy to locate areas with seemingly suitable habitat where Baird's Sparrows are either not present or found in low densities.

\section{METHODS}

We constructed playback stations at two different sites within the breeding range of Baird's Sparrows. Plots (9-ha) were established near Chase Lake National Wildlife Refuge $(N=6$; $\left.47^{\circ} 02^{\prime} \mathrm{N}, 099^{\circ} 24^{\prime} \mathrm{W}\right)$ and at Lostwood National Wildlife Refuge $\left(N=6 ; 48^{\circ} 37^{\prime} \mathrm{N}, 102^{\circ} 26^{\prime} \mathrm{W}\right)$. Both sites were characterized by rolling hills of upland prairie interspersed with numerous wetlands. Principal vegetation included mixedgrass prairie dominated by Stipa and Agropyron grasses, and the dominant woody species were western snowberry (Symphoricarpos occidentalis), silverberry (Elaeagnus commutata), and quaking aspen (Populus tremuloides).

Plots were in areas where no Baird's Sparrows were known to occur the previous 2 yr based on our observations and those of refuge personnel. Although formal surveys were not conducted, Baird's Sparrows were studied in nearby areas during the previous $2 \mathrm{yr}$, and field crews knew the location of most territories in the vicinity. All plots within a site were at least $1 \mathrm{~km}$ apart, and the two sites (Chase Lake and Lostwood) were about $350 \mathrm{~km}$ apart. To control for landscape features, all plots were in tracts of grassland at least 50 ha in size with at least $50 \%$ of the area within a $1-\mathrm{km}$ radius in grassland cover (Johnson and Igl 2001, Davis 2004). Within each site, three plots were randomly assigned to the playback treatment and the remaining three were used as control plots. 
We established two playback stations on each experimental plot. Each station generally followed the design of Ward and Schlossberg (2004) and consisted of a portable compact-disc (CD) player with speakers (MP3838; Memorex Products, Inc., Cerritos, CA) wired to a $12-\mathrm{V}$ battery through a Diehl timer (Borg General Controls, Elk Grove Village, IL). Batteries were powered by a ST-10 solar panel (Northern Arizona Wind and Sun, Flagstaff, AZ). We mounted CD players inside waterproof containers with mesh screen on one side to allow songs to be broadcast and bolted them to plywood platforms. In the field we assembled the platforms about $0.5 \mathrm{~m}$ above ground to simulate the height at which Baird's Sparrows typically sing (Green et al. 2002). We did not use decoy models because previous investigators of songbirds have found they were not necessary to elicit a response (Alatalo et al. 1982, Ward and Schlossberg 2004).

We began broadcasting songs from playback stations on 5 May 2004 near Chase Lake and on 9 May 2004 at Lostwood. Songs were broadcast every morning from 04:30 to 10:30 CST, and playback stations were turned off and taken down after the last round of censusing on 15 July at Lostwood and 24 July at Chase Lake. Songs were broadcast at maximum volume, and at that level, we could hear the playbacks from about the same distance that we could later hear the singing of neighboring males. Each CD contained 60.4 min of Baird's Sparrow songs (recorded from five different males) and $10.95 \mathrm{~min}$ of songs of Grasshopper Sparrows (Ammodramus savannarum; $2.03 \mathrm{~min}$ ), Claycolored Sparrows (Spizella pallida; $2.9 \mathrm{~min}$ ), Savannah Sparrows (Passerculus sandwichensis; $1.87 \mathrm{~min}$ ), Sprague's Pipits (Anthus spragueii; $2.33 \mathrm{~min}$ ), and Western Meadowlarks (Sturnella neglecta; $1.82 \mathrm{~min}$ ). Ten minutes of silence followed each round of songs. The songs of other species that occur in the area were played to keep Baird's Sparrows from habituating to the playbacks (Ward and Schlossberg 2004). Song tracks used on the CDs were recorded from birds at or near Lostwood National Wildlife Refuge and obtained through the Borror Laboratory of Bioacoustics at Ohio State University (BLB No.: 10843, 10846, 11396, 11397, 12493).

To measure the response of the birds to the playbacks, we visited each of the 12 plots once a week for approximately $45 \mathrm{~min}$ each and used standard spot-mapping techniques (Robbins 1970, Ralph et al. 1993) to determine the density of Baird's Sparrows on each plot and record any reproductive activity. We measured habitat variables on the sites to: (1) compare habitat characteristics between the two treatments, and (2) determine whether the pattern of Baird's Sparrow settlement could be explained by vegetation differences between the plots. We sampled 36 random vegetation points on each plot, stratified by 50 -m grid transects established on the plots. Using a Daubenmire frame, we estimated cover of the following features to the nearest $5 \%$ : overall amount of green vegetation, live grass, live forbs, standing litter $\left(\geq 45^{\circ}\right.$ from horizontal), down litter $\left(<45^{\circ}\right.$ from horizontal), bare ground, and woody vegetation (Daubenmire 1959). We also recorded the number of woody stems within the Daubenmire frame. We used Wiens' rods to measure vegetation density (the number of vegetation hits on the rod) in $10 \mathrm{~cm}$ increments, vegetation height, and litter depth (Wiens 1969). Finally, we recorded any plant species with an estimated cover $>25 \%$ as a dominant species, and recorded no dominant species if no species covered more than $25 \%$ of the frame.

To analyze the occurrence of Baird's Sparrows in relation to the treatment, we compared the number of occupied and unoccupied plots by treatment using a one-sided Fisher exact test because our sample size was small (SAS 1996, Zar 1999). We used plots as experimental units.

Although we established plots based on apparent similarity of vegetation and randomly assigned the treatment to plots, we nonetheless tested for similarity of vegetation between treatment and control plots. We compared the two treatments on the basis of means, standard errors, and confidence intervals of all the vegetation variables measured. The cover categories "live grass" and "live forbs" were combined to obtain a "live vegetation" category, and "standing litter" and "down litter" were combined to obtain a "residual vegetation" category. To examine similarity in species composition, we compared the same statistics for the frequency of dominant plant species on the control and treatment plots. In addition, we performed a regression analysis using four representative vegetation features (cover by woody vegetation (\%), litter depth $(\mathrm{cm})$, vegetation height $(\mathrm{dm})$, and density of vegetation in the first $20 \mathrm{~cm}$ ) to determine if 
they influenced bird density irrespective of the treatment. These four variables represented the broad categories of vegetation measured. For this analysis, we looked at variation over all plots in both treatments and variation within treatment plots only. All values are presented as mean \pm $1 \mathrm{SE}$.

\section{RESULTS}

No Baird's Sparrows settled on any of the six control plots $(N=6)$, whereas six males established territories on three of the six playback plots, with one, two and three males on each of the three colonized plots, respectively. The mean density of males on the playback plots was $0.15 \pm 0.10$ per ha at Chase Lake $(N=3)$ and $0.07 \pm 0.07$ per ha at Lostwood $(N=3)$. Overall, mean density on the playback plots $(N=6)$ was $0.11 \pm 0.06$ males per ha. Differences between playback and control plots in the number of males present approached significance (one-sided Fisher's exact test; $P=$ $0.09, N=12$ ).

Baird's Sparrows were first observed at Lostwood on 16 May 2004 and on 17 May 2004 at Chase Lake. Males on the playback plots established territories adjacent to the playback stations. Although not quantified, males were sometimes observed counter-singing with the recordings (i.e., singing during the intervals between successive played-back songs) during the first 2-3 weeks. Counter-singing was observed less often during late June and July. During the first 2 weeks of the experiment, we sometimes observed Baird's Sparrows counter-singing while perched on playback stations even though other perches were available nearby. Territorial males were observed on playback plots $1-4 \mathrm{~d}$ after Baird's Sparrows were first reported on the refuges in 2004 and they remained on the plots until playback was discontinued in July.

We observed one male engaged in a characteristic tail-chasing courtship behavior with another individual presumed to be a female, and this putative pair was observed together on one other occasion with no apparent display of aggressive behavior. No other individuals were observed in the territories of the remaining five males.

Based on $95 \%$ confidence intervals, characteristics of vegetation on the playback and control plots did not differ (Table 1), with substantial overlap between the two treatments in all variables. Similar overlap was found for playback plots with and without males present. Although located in predominantly native prairie, the two dominant species on the plots were exotic species (Kentucky bluegrass [Poa pratensis] and smooth brome [Bromus inermis]). However, there was no difference in the frequency of either species between treatments (Table 1).

Finally, we tested to see if any underlying vegetation patterns explained the variation in settlement patterns over all plots and within treatment plots alone. With ordinary linear regression on

Table 1. Vegetation characteristics of playback $(N=6)$ and control $(N=6)$ plots at Lostwood and Chase Lake National Wildlife Refuges in 2004.

\begin{tabular}{lrr}
\hline & \multicolumn{1}{c}{ Playback $^{\mathrm{a}}$} & Control $^{\mathrm{a}}$ \\
\hline Green vegetation $^{\mathrm{b}}(\%)$ & $42.80 \pm 3.28$ & $39.54 \pm 1.69$ \\
Live vegetation $^{\mathrm{c}}(\%)$ & $42.80 \pm 3.30$ & $39.47 \pm 1.65$ \\
Residual vegetation (\%) & $45.20 \pm 2.45$ & $48.15 \pm 3.49$ \\
Bare ground (\%) & $7.33 \pm 1.94$ & $8.76 \pm 1.81$ \\
Woody vegetation (\%) & $6.19 \pm 1.70$ & $5.33 \pm 1.27$ \\
Number of woody stems & $3.04 \pm 1.44$ & $2.08 \pm 0.97$ \\
Density from 0 to 20 cm ${ }^{\mathrm{d}}$ & $7.43 \pm 1.27$ & $6.42 \pm 0.67$ \\
Vegetation height (dm) $_{\text {Litter depth (cm) }}$ & $1.97 \pm 0.08$ & $1.72 \pm 0.12$ \\
Frequency of Kentucky bluegrass & $1.61 \pm 0.33$ & $1.45 \pm 0.17$ \\
Frequency of smooth brome & $0.20 \pm 0.04$ & $0.23 \pm 0.07$ \\
\hline
\end{tabular}

\footnotetext{
${ }^{a}$ Values presented as mean $\pm 1 \mathrm{SE}$.

${ }^{\mathrm{b}}$ Any green vegetation (not including colorful parts of flowers, woody stems, or residual vegetation).

cAny live vegetation regardless of color.

${ }^{\mathrm{d}}$ Number of vegetation hits on the rod from 0 to $20 \mathrm{~cm}$ above ground.
} 
the four representative structural variables described above, none of the variables explained appreciable variation in the density over all plots together or within only the treatment plots $(P=$ $0.23, F_{4,7}=1.84, N=12 ; P=0.66, F_{4,1}=$ $0.86, N=6)$.

\section{DISCUSSION}

Three of our six playback plots were colonized by six males, suggesting that Baird's Sparrows may use the presence of conspecifics in habitat selection decisions. Playback of heterospecific songs in our study may have also influenced settlement because some species appear to use the presence of heterospecific birds as a cue for territory establishment (Monkkonen et al. 1999, Thomson et al. 2003, Parejo et al. 2004). However, we believe it unlikely that male Baird's Sparrows responded to the songs of heterospecifics because (1) heterospecific songs were played only briefly compared to Baird's Sparrow songs, (2) all species represented on our playback CD naturally occurred on the plots and were detected during censuses for Baird's Sparrows, and (3) the response of males to playback of conspecific songs when males were establishing territories suggests that those songs probably had the greatest influence on settlement patterns.

Although the mean density of Baird's Sparrows on treatment plots $\left(0.11\right.$ males $\left.\mathrm{ha}^{-1}\right)$ was within the range of densities on other nonmanipulated study sites on the refuges and other locations in Saskatchewan (0.02-0.32 males $\mathrm{ha}^{-1}$; Ahlering unpubl. data), not all playback sites were colonized. Spatial variability in grassland habitat (Bragg 1995, Knopf and Samson 1997) may lead to the natural variation in the distribution of populations of some grassland species (Winter et al. 2005), but conspecific attraction may also explain some of this variation (Smith and Peacock 1990, Ray et al. 1991). Some grassland species tend to occur at low densities (Cody 1985b) and, therefore, the settlement of birds may be erratic and patchy even in suitable habitat. The low densities of Bairds' Sparrows on our playback plots, and the fact that not all experimental plots were colonized, could be a result of this erratic distribution of birds. At low densities conspecific attraction could be the result of an Allee effect, increasing the fitness of individuals as density increases to some threshold (Greene and Stamps 2001).
Even within patches of suitable habitat, without some mechanism like conspecific attraction to aggregate birds, it could be more difficult for isolated individuals to attract mates. An improved understanding of the importance of conspecifics in making settlement decisions could help us better understand the seemingly erratic population shifts and nomadic movements of some species of grassland birds (Zimmerman 1992, Igl and Ballard 1999, Greene and Stamps 2001).

If conspecific attraction does occur in some species of grassland birds, as our results suggest, then the mechanisms by which it operates for more nomadic species and its implications for conservation and management may be different than for more site-faithful species. Birds that return to the same breeding sites or regions in subsequent years may use information about the productivity of a site the previous year (Bollinger and Gavin 1989, Doligez et al. 2002) or the location of adults at the end of one breeding season in their habitat selection decisions for the following year (Nocera et al. 2006). However, the nomadic tendencies of Baird's Sparrows (Green 1992, Ahlering unpubl. data) suggest that information about previous breeding seasons plays a limited role in habitat selection.

A central goal in avian ecology is to understand the relationship between a species and its habitat (Hilden 1965, Cody 1985a). The focus is often on landscape and vegetation features, but our results demonstrate that social factors should also be considered (Reed and Dobson 1993, Sutherland 1998, Ahlering and Faaborg 2006). Although we found that playback of conspecific songs attracted birds to previously unoccupied, potentially suitable habitat, further experiments are needed to examine the importance of conspecific attraction relative to other cues that birds may use, such as vegetation features.

The conservation and management implications of conspecific attraction are not completely understood, but the presence of conspecifics should be considered a potential cue in habitat selection by all species of birds. Decoys and playbacks have been used previously to establish new colonies of colonial-nesting species (Kotliar and Burger 1984, Kress and Nettleship 1988, Podolsky 1990, Jeffries and Brunton 2001). However, our results and those of other investigators (Alatalo et al. 1982, Ward and Schlossberg 2004, Hahn and Silverman 2006) indicate that territorial songbirds may respond 
similarly. Before attempting to use conspecific attraction to manage populations of any species, we need to better understand the consequences of attracting birds into new habitats (Ahlering and Faaborg 2006). However, regardless of the potential management applications, a better understanding of the habitat selection process of birds will enhance our ability to provide suitable habitat.

\section{ACKNOWLEDGMENTS}

We thank the staff at USGS Northern Prairie Wildlife Research Center for logistical support and assistance. We are grateful to the staff at Chase Lake National Wildlife Refuge, Lostwood National Wildlife Refuge, and the North Dakota Game and Fish Department for additional support, assistance, and permission to access land. Special thanks to the field crew: L. Collie, C. Craig, K. MacKinnon, and M. Phillips. Thanks to J. W. Bailey, C. McGowan, C. Merkord, D. Morris, M. S. Pruett, C. Rittenhouse, M. Ryan, K. Suedkamp Wells, and J. White for reviewing this manuscript. This study was funded by the USGS Northern Prairie Wildlife Research Center, Jamestown, ND.

\section{LITERATURE CITED}

Ahlering, M. A., AND J. FaAborg. 2006. Avian habitat management meets conspecific attraction: if you build it will they come? Auk 123: 301-312.

Alatalo, R. V., A. LundberG, AND M. Bjorklund. 1982. Can the song of male birds attract other males? An experiment with the Pied Flycatcher Ficedula hypoleuca. Bird Behaviour 4: 42-45.

Bollinger, E. K., AND T. A. GAVIN. 1989. The effects of site quality on breeding-site fidelity in Bobolinks. Auk 106: 584-594.

BRAGG, T. B. 1995. The physical environment of Great Plains grasslands. In: The changing prairie (A. Joern, and K. H. Keeler, eds.), pp. 49-81. Oxford University Press, New York.

$\longrightarrow$, AND A. A. STeuter. 1996. Prairie ecology-the mixed prairie. In: Prairie conservation (F. B. Samson, and F. L. Knopf, eds.), pp. 53-65. Island Press, Washington, D.C.

Cody, M. L. 1985a. An introduction to habitat selection in birds. In: Habitat selection in birds (M. L. Cody, ed.), pp. 3-56. Academic Press, San Diego, CA.

1985b. Habitat selection in grassland and opencountry birds. In: Habitat selection in birds (M. L. Cody, ed.), pp. 191-226. Academic Press, San Diego, CA.

Danchin, E., T. Boulinier, And M. Massot. 1998. Conspecific reproductive success and breeding habitat selection: implications for the study of coloniality. Ecology 79: 2415-2428.

DAUBENMiRE, R. F. 1959. A canopy coverage method of vegetational analysis. Northwest Science 35: 43-64.

DAVIS, S. K. 2004. Area sensitivity in grassland passerines: effects of patch size, patch shape, and vegetation structure on bird abundance and occurrence in southern Saskatchewan. Auk 121: 1130-1145.

Doligez, B., E. DANChin, AND J. Clobert. 2002. Public information and breeding habitat selection in a wild bird population. Science 297: 1168-1170.

, T. Part, E. Danchin, J. Clobert, and L. GuSTAFSSON. 2004. Availability and use of public information and conspecific density for settlement decisions in the Collared Flycatcher. Journal of Animal Ecology 73: 75-87.

ETTERSON, M. A. 2003. Conspecific attraction in Loggerhead Shrikes: implications for habitat conservation and reintroduction. Biological Conservation 114: 199-205.

Fletcher, R. J., AND C. W. Miller. 2006. On the evolution of hidden leks and the implications for reproductive and habitat selection behaviours. Animal Behaviour 71: 1247-1251.

FreTwell, S. D., AND H. L. LuCAS. 1970. On territorial behavior and other factors influencing habitat distribution in birds. I. Theoretical development. Acta Biotheoretica 19: 16-36.

George, T. L., A. C. Fowler, R. L. Knight, And L. C. MCEWEN. 1992. Impacts of a severe drought on grassland birds in western North Dakota. Ecological Applications 2: 275-284.

GreEN, M. T. 1992. Adaptations of Baird's Sparrows (Ammodramus bairdii) to grasslands: acoustic communication and nomadism. Ph.D. dissertation. University of North Carolina, Chapel Hill, NC.

- P. E. Lowther, S. L. Jones, S. K. Davis, And B. C. DALE. 2002. Baird's Sparrow (Ammodramus bairdii). In: The birds of North America (A. Poole, and F. Gill, eds.). The Birds of North America Inc., Philadelphia, PA.

Green, C.M., AND J. A. STAmps. 2001. Habitat selection at low population densities. Ecology 82: 2091-2100.

Hahn, B. A., And E. D. Silverman. 2006. Social cues facilitate habitat selection: American Redstarts establish breeding territories in response to song. Biology Letters 2: 337-340.

Hilden, O. 1965. Habitat selection in birds. Annales Zoologici Fennici 2: 53-75.

IGL, L. D., AND B. M. BALLARD. 1999. Habitat associations of migrating and overwintering grassland birds in southern Texas. Condor 101: 771-782. , AND D. H. JoHnson. 1999. Le Conte's Sparrows breeding in conservation reserve program fields: precipitation and patterns of population change. Studies in Avian Biology 19: 178-186.

JefFries, D. S., AND D. H. Brunton. 2001. Attracting endangered species to 'safe' habitats: responses of Fairy Terns to decoys. Animal Conservation 4: 301305.

JOHNSON, D. H., AND L. D. IGL. 2001. Area requirements of grassland birds: a regional perspective. Auk 118: 24-34.

Knopf, F. L., And F. B. SAmson. 1997. Conservation of grassland vertebrates. In: Ecology and conservation of Great Plains vertebrates (F. L. Knopf, and F. B. Samson, eds.), pp. 273-289. Springer-Verlag, New York.

Kotliar, N. B., AND J. Burger. 1984. The use of decoys to attract Least Terns (Sterna antillarum) 
to abandoned colony sites in New Jersey. Colonial Waterbirds 7: 134-138.

Kress, S. W., and D. N. NeTtleship. 1988. Reestablishment of Atlantic Puffins (Fratercula arctica) at a former breeding site in the Gulf of Maine. Journal of Field Ornithology 59: 161-170.

MÖnKKÖnen, M., R. Hardling, J. T. Forsman, And J. TUOMI. 1999. Evolution of heterospecific attraction: using other species as cues in habitat selection. Evolutionary Ecology 13: 91-104.

Nocera, J. J., G. J. Forbes, and L. A. Giraldeau. 2006. Inadvertent social information in breeding site selection of natal dispersing birds. Proceedings of the Royal Society of London B 273: 349-355.

Parejo, D., E. Danchin, AND J. M. Aviles. 2004. The heterospecific habitat copying hypothesis: can competitors indicate habitat quality? Behavioral Ecology 16: 96-105.

PODOLSKY, R. H. 1990. Effectiveness of social stimuli in attracting Laysan Albatross to new potential nesting sites. Auk 107: 119-125.

Ralph, C. J., G. R. Geupel, P. Pyle, T. E. Martin, and D. F. DESANTE. 1993. Handbook of field methods for monitoring landbirds. USDA Forest Service. General Technical Report PSW-GTR-144. Pacific Southwest Research Station, Albany, CA.

Ray, C., M. Gilpin, AND A. T. SMith. 1991. The effect of conspecific attraction on metapopulation dynamics. Biological Journal of the Linnean Society 42: 123134.

Reed, J. M., And A. P. Dobson. 1993. Behavioural constraints and conservation biology: conspecific attraction and recruitment. Trends in Ecology and Evolution 8: 253-256.

RobBins, C. 1970 . Recommendations for an international standard for a mapping method in bird census work. Audubon Field Notes 24: 723-726.

SAS INSTITUTE. 1996. SAS/STAT User's guide. Version 6.12. SAS Institute, Inc., Cary, NC.

Sauer, J. R., J. E. Hines, and J. Fallon. [online]. 2005. The North American Breeding Bird Survey, results and analysis 1966-2004. Version 2005.2. USGS Patuxent Wildlife Research Center. Laurel, MD. http://www.mbr-pwrc.usgs.gov/bbs/bbs.html.

Sergio, F., And V. Penteriani. 2005. Public information and territory establishment in a loosely colonial raptor. Ecology 86: 340-346.

Serrano, D., M. G. Forero, J. A. Donazar, and J. L. TELLA. 2004. Dispersal and social attraction affect colony selection and dynamics of Lesser Kestrels. Ecology 85: 3438-3447.

SKIPPER, C. S. 1998. Henslow's Sparrows return to previous nest site in western Maryland. North American Bird Bander 23: 36-41.

Smith, A. T., And M. M. Peacock. 1990. Conspecific attraction and the determination of metapopulation colonization rates. Conservation Biology 4: 320-323.

STAMPS, J. A. 1988. Conspecific attraction and aggregation in territorial species. American Naturalist 131: 329-347.

Suryan, R. M., And D. B. Irons. 2001. Colony and population dynamics of Black-legged Kittiwakes in a heterogeneous environment. Auk 118: 636-649.

SuTHERLAND, W. J. 1998. The importance of behavioural studies in conservation biology. Animal Behaviour 56: 801-809.

TARof, S. A., AND L. M. RatClifFe. 2004. Habitat characteristics and nest predation do not explain clustered breeding in Least Flycatchers (Empidonax minimus). Auk 121: 877-893.

, L. M. Ratcliffe, M. M. Kasumovic, and P. T. BOAG. 2005. Are Least Flycatcher (Empidonax minimus) clusters hidden leks? Behavioral Ecology 16: 207-217.

Thomson, R. L., J. T. Forsman, And M. MÖnKKÖNEN. 2003. Positive interactions between migrant and resident birds: testing the heterospecific attraction hypothesis. Oecologia 134: 431-438.

WAGNER, R. H. 1998. Hidden leks: sexual selection and the clustering of avian territories. In: Avian reproductive tactics: female and male perspectives (P. G. Parker, and N. T. Burley, eds.), pp. 123-145. American Ornithologists' Union, Washington, D.C.

WARD, M., AND S. SCHLOSSBERG. 2004. Conspecific attraction and the conservation of territorial songbirds. Conservation Biology 18: 519-525.

WiENS, J. A. 1969. An approach to the study of ecological relationships among grassland birds. Ornithological Monographs 8: 1-93.

Winter, M., D. H. Johnson, And J. A. Shaffer. 2005. Variability in vegetation effects on density and nesting success of grassland birds. Journal of Wildlife Management 69: 185-197.

ZaR, J. H. 1999. Biostatistical analysis. Prentice-Hall, Upper Saddle River, NJ.

ZiMMERMAN, J. L. 1992. Density-independent factors affecting the avian diversity of the tallgrass prairie community. Wilson Bulletin 104: 85-94. 